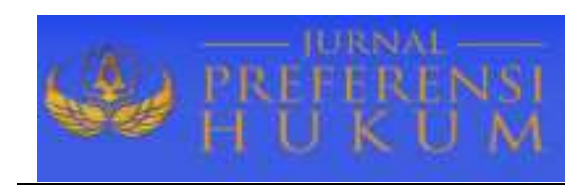

Jurnal Preferensi Hukum | ISSN: 2746-5039

Vol. 2, No. 2 - Juli 2021, Hal. 243-247| Available online at https://www.ejournal.warmadewa.ac.id/index.php/juprehum

DOI: https://doi.org/ 10.22225/jph.2.2.3316.243-247

\title{
PERLINDUNGAN HUKUM TERHADAP KONSUMEN YANG DIRUGIKAN ATAS KELALAIAN PELAKU USAHA CUCI SEPATU DI DENPASAR TIMUR
}

\author{
I Wayan Indra Adi Wicaksana, I Nyoman Putu Budiartha, Ni Made Puspasutari Ujianti \\ Fakultas Hukum, Universitas Warmadewa, Denpasar-Bali, Indonesia \\ indraadiw@yahoo.com, budiarthaputu59@gmail.com, puspasutariujianti@gail.com
}

\begin{abstract}
Abstrak
Minat masyarakat akan sepatu menjadi kebutuhan khusus, sepatu sangat diminati oleh kaum milenial karena berguna untuk melindungi kaki. Adanya kebiasaan dalam mengoleksi sepatu ini maka timbullah keinginan manusia untuk menjaga barangnya agar tidak cepat rusak dan tetap bersih dengan waktu yang lama. Dengan adanya jasa cuci sepatu kini telah meringankan pekerjaan masyarakat dan menghemat tenaga maupun waktu. Namun masih terdapat kasus kerusakan pada sepatu yang menyebabkan kerugian pada konsumen dan tidak ada pertanggungjawaban dari pihak jasa cuci sepatu. Penelitian ini mengkaji faktor yang menimbulkan kerusakan sepatu konsumen oleh pelaku usaha cuci sepatu di Denpasar Timur dan menjelaskan upaya penyelesaian yang dapat dilakukan konsumen apabila pelaku usaha tidak bertanggung jawab atas kerugian yang diterima oleh. Metode penelitian yang digunakan adalah tipe hukum empiris dengan tujuan untuk menemukan fakta. Data yang digunakan bahan hukum primer dan sekunder yang diperoleh melalui wawancara, pencatatan. Adapun faktor internal dan ekstemal yang menimbulkan kerusakan sepatu konsumen oleh pelaku usaha. Upaya penyelesaian yang dapat dilakukan konsumen apabila pelaku usaha tidak bertanggung jawab dengan upaya non litigasi dan litigasi. Sehingga pertanggungjawaban atas kerugian tidak dapat dilakukan secara sepihak antara pelaku usaha maupun konsumen karena adanya upaya hukum yang dapat ditempuh apabila dirugikan. Maka dengan adanya Undang-undang Nomor 8 Tahun 1999 tentang Perlindungan Konsumen perlu diketahui oleh kedua belah pihak agar hak-hak dan kewajiban tidak dilanggar.
\end{abstract}

Kata Kunci: Litigasi, Non Litigasi, Usaha Cuci Sepatu,Tanggung jawab

\begin{abstract}
Public interest in shoes is a special need, shoes are in great demand by millennials because they are useful for protecting feet. The habit of collecting these shoes arises from the desire of humans to keep their goods so they don't get damaged quickly and stay clean for a Long time. However, there are still cases of damage to shoes that cause Losses to consumers and there is no responsibility from the shoe washing service. The research method used is the type of empirical Law, empirical legal research aims to find facts, and conduct interviews. There are internal and external factors that cause damage to consumer shoes by business actors. So that responsibility for losses cannot be carried out unilaterally between business actors and consumers because there are Legal remedies that can be taken if they are harmed. Lack of knowledge and understanding fromconsumers, makes the position of consumers lower than business actors. So with the existence of Law Number 8 of 1999 concerning Consumer Protection, both parties need to know so that their rights and obligations are not violated.
\end{abstract}

Keywords: Responsibility, Non Litigation, Litigation

\section{PENDAHULUAN}

Dunia usaha tidak bisa lepas dari kehidupan masyarakat sekitar, oleh karenanya pelaku usaha harus mampu beradap tasi dengan masyarakat sekitar guna mendukung usaha tersebut. selain itu pelaku uasaha harus melihat peluan usaha tersebut terhadap kemanfaatan terhadap warga sekitar. Efektifnya suatu usah dikarenakan sistem pemasaran yang baik serta manfaat jasa atau barang yang ditawarkan kepada konsumen (Lukitaningsih, 2013). Masyarakat dengan pelaku usaha saling berhunngan. Adanya konsumen dalam setiap kegiatan us aha tentunya juga ada produsen atau pelaku usaha. Pelaku usaha tentunya mempunyai hak untuk mendapatkan perlindungan namun masing-masing dari konsumen dan pelaku usaha tentunya memiliki prinsip, hak dan kewajiban yang tidak sama. Perbedaan prinsip antara 
konsumen dan pelaku usaha dapat dilihat dari konsumen yang tenrunya menginginkan barang atau jasa yang diburuhkan untuk memenuhi kebutuhan hidupnya, sedangkan pelaku usaha membuat atau menjual barang atau jasanya untuk mendapat keuntungan bagi dirinya maupun usahanya. Pada dasarnya dalam kegiatan usaha barang/jasa, pelaku usaha dengan konsumen mernbentuk simbiosis mutualisme artinya pelaku usaha dengan konsumen saling menguntungkan karena satu sama lain terlibat dalam satu ikatan yang saling membutuhkan (Handayani, 2008).

Kegiatan cuci sepatu tentunya terlihat mudah karena membutuhkan air dan sabun cuci sepatu, tetapi pada kenyataanya pad a masa i ni masyarakat ban yak mencari jasa cuci sepatu agar kebersihan yang didapatkan bisa maksimal. Maka dari itu banyak bermunculan jasa- jasa cuci sepatu yang tersebar di Kota Denpasar, yang pada saat ini saya mengambil sampel di salah satu jasa cuci sepatu di Denpasar. Dari beberapa wawancara terhadap konsumen diketahhui bahwa masih banyak kasus kerusakan pada sepatu konsumen. Hal ini terjadi karena kurangnya kehati-hatian pelaku usaha laundri dalam mencuci , selanjutnya dan pelaku usaha yang melakukan wanprestasi membuat kedudukan konsumen lebih rendah dari pelaku usaha. Penyampaian informasi kepada konsumen yang dilakukan oleh pelaku usaha seyogyanya disampaikan secara proporsional. Ada juga beberapa kerusakkan bukan karena disengaja melainkan memang hasil dari cucian dari mesin cuci trsebut yang kadang mengakibatkan tergores dan memudarnya warna sepatu cucian. Mengatisipasi hal ini sebaiknya pelaku usaha tidak hanya menginformasikan keunggulan atau kekhasan produknya saja, melainkan juga mengenai kerugian konsumen dalam penggunaan barang atau jasa yang dijualnya (Widyani, 2020). Penelitian terdahulu mengungkapkan konsumen yang mengalami kehilangan kesadaran yang menyebabkan terjadinya perkelahian dan pertengkaran sesama teman mereka yang menyebabkan timbulnya kerusakan, maka bisa diselesaikan secara musyawrah dan juga secara hukum (Trisno, 2017).

Berdasarkan uraian dan teori terdahulu maka penelitian ini mengkaji faktor yang menimbulkan kerusakan sepatu konsumen oleh pelaku usaha cuci sepatu di Denpasar Timur dan menjelaskan upaya penyelesaian yang dapat dilakukan konsumen apabila pelaku usaha tidak bertanggung jawab atas kerugian yang diterima oleh konsumen.

\section{METODE PENELITIA}

Penelitian ini menggunakan penelitian empiris, atau biasa disebut dengan penelitian lapangan yang dimana penulis mengkaji ketentuan hukum yang berlaku serta apa yang terjadi dalam kenyataannya dalam masyarakat berdasarkan masalah yang dikaji. Karena ini masih mengkaji tentang perlindungan hukum, maka penedekatan yang diguankan adalah pendekatan Perundang-undangan serta pendekatan masalah. Mengenai sumber data yang digunakan dalam menunjang penelitian ini yaitu sumber data primer dan sumber data sekunder. Data primer yaitu data yang bersumber langsung dari penelitian di lapangan dan data sekunder diperoleh dari dokumen secara teknis dari sumber /bacaan, literaturliteratur, pendapat ahli, serta peraturan Perundang- undangan yang terkait dengan masalah yang diteliti. Data penelitian diperoleh melalui teknik wawancara, menvatat da dokumentasi arsip. Setelah semunya data terkumpul, mak peneliti menganalisis dengan analisis hukum sistematis.

\section{HASIL DAN PEMBAHASAN}

\section{Faktor Yang Menimbulkan Kerusakan Sepatu Konsumen oleh Pelaku}

Konsep perlindungan hukum di Indonesia harus dimaknai adalah penghayatan atas kesadaran akan perlindungan bagi harkat dan martabat manusia yang bersumber pada asas Negara Hukum Pancasila (Atmadja \& Budiartha, 2018). Hubungan hukum antara konsumen dengan pelaku usaha didasarkan pada suatu ikatan, baik yang berasal dari perjanjian maupun Undang-undang (Subekti, 2002). Sebagai pemakai barang dan/atau jasa, konsumen merniliki sejumlah hak dan kewajiban. Pengetahuan tentang hak konsumen sangat penting agar konsumen dapat bersikap dengan kritis dan mandiri. Tujuannya apabila ada tindakan yang tidak adil, konsurnen dapat secara spontan menyadari akan hal itu. Konsumen kemudian dapat bertindak lebih jauh untuk memperjuangkan haknya, dengan kata lain konsumen dapat menyadari bahwa haknya telah dilanggar (Susanto, 2008).

Dari sembilan butir hak-hak konsumen yang terdapat dalam Undang-Undang Nomor 8 Tahun 1999 tentang Perlindungan Konsumen, terlihat bahwa kenyamanan, keamanan, serta keselamatan konsumen merupakan hal yang paling penting dan utama dalam perlindungan konsumen, maupun perlindungan konsumen cuci sepatu. Selain memiliki hak, konsumen juga mempunyai kewajiban yang harus dilaksanakan seperti rnengikuti petunjuk inforrnasi demi keamanan dan keselamatan, beritikad 
baik, rnembayar sesuai kesepakatan yang ada, serta mengikuti segala upaya penyelesaian sengketa apabila terjadi sengketa antara kedua belah pihak. Ada pula hak yang harus dihargai oleh konsumen kepada pelaku usaha yang diatur dalam Pasal 6 Undang-Undang No 8 Tahun 1999 tentang Perlindungan Konsumen. Selain memiliki hak yang harus dihargai dan dilindungi pelaku usaha dalam menjalankan usahanya, pelaku usaha tentunya merniliki kewajiban yang harus dilakukan demi memuaskan konsumen yang menggunakan barang atau jasanya.

Kewajiban pelaku us aha terse but diatur dalam Pasal 7 U ndang-U ndang Nomor 8 Tahun 1999 tentang Perlindungan Konsumen. Jika diperhatikan dengan baik lagi, kewajiban dari pelaku usaha merupakan implernentasi dari hak-hak konsumen dalam sisi yang ditargetkan unruk rnenciptakan budaya tanggung jawab dari pelaku usaha. Dari hasil wawancara ditiga tempat atau jasa cuci sepatu di Denpasar Timur, tentunya memiliki Hak dan Kewaj iban yang berbeda, yang pertama pada tanggal 14 Desember 2020 di jasa cuci sepatu yang bemama Hoki Clean Shoes yang terletak di Jl. Sokasati No. 10 Kesiman, Denpasar Timur, jasa cuci sepatu ini berdiri dari tahun 2018 dan didirikan oleh saudara Agus Pratama Putra sekaligus pemilikjasa sampai saat ini. Beliau menjelaskan, apabila konsumen yang ingin menggunakan jasa dari usahanya harus memiliki rasa percaya terhadap jasa yang akan digunakan, karena kami tidak memiliki perjanjian tertulis, sedangkan konsumen hanya mendapat nota tanda ada transaksi yang dilakukan antara kedua belah pihak yaitu. Kedua tanggal yang sama yaitu tanggal 14 Desember 2020 di jasa cuci sepatu yang bemama KEDASIN yang beralamat di JI. Trengguli No. 21 Penatih, Denpasar Timur. Usaha yang bergerak di bidang jasa cuci sepatu ini didirikan oleh Gung Deva pada tahun 2018. Dari hasil wawancara diketahui bahwa Hak dari dia sebagai pelaku usaha mengikuti Undang-undang yang berlaku, yang mana yang menjadi poinnya adalah menerima pembayaran dari konsurnen sesuai dengan kesepakatan yang ada. Ketiga yaitu jasa cuci sepatu JDCKSS, wawancara via telepon pada tanggal 15 Desember 2020 karenajasa cuci sepatu tersebut tidak mempunyai toko. Jasa cuci sepatu ini tergolong baru karena baru didirikan oleh saudara Indra Paradiptha dengan rekannya tahun 2020. Jasa yang ia sediakan tersebut dilakukan di rumah sendiri atau biasa disebut dengan home service, karena belum ada toko tetap untuk para konsumen meletakan dan mengambil sepatu yang dicuci atau treatment lainnya. Walaupun tidak seperti jasa lainnya yang memiliki toke, ia mengatakan bahwa hak dan kewajiban antara pelaku usaha dan konsumen tetap ada dan tetap harus dilaksanakan, hat itu dikarenakan setiap usaha dan transaksi yang dilakukan harus mempunyai hak dan kewajiban untuk dipenuhi.

Faktor-faktor yang menimbulkan kerusakan sepatu konsumen oleh pelaku usaha cuci sepatu di bagi menjadi dua faktor, yaitu faktor internal dan faktor eksternal. Faktor internal biasanya datang dari manusia iru sendiri yang dimana manusia tersebut adalah pelaku usaha serta pegawainya. Faktor internal timbul akibat

a. Lalai

Faktor kelalaian tentu dari manusia itu sendiri, kelalaian terjadi karena kurangnya konsentrasi bekerja dalam hal ini pengerjaan sepatu sehingga dapat merusak sepatu dari konsumen. Selain itu pelaku usaha lalai dalam melakukan komunikasi kepada pegawainya ataupun konsumen perihal kondisi sepatu sebelum diterima.

b. Pengalaman

Pengalaman diajukan untuk kewaspadaan terhadap kecelakaan kerja atau kerusakan pada sepatu konsumen akan lebih baik dan teliti apabila dipandang dari lamanya pegawai tersebut bekerja di jasa cuci septum. Karena semakin Jama pegawai bekerja, semakin kecil faktor yang dapat menimbulkan kerusakan pada sepatu konsumen. Sehingga Jebih baik pelaku usaha mencari pegawai yang lebih berpengalaman agar kerugian yang diterima apabila terjadi kerusakan pada sepatu konsumen semakin kecil.

c. Kedisiplinan

Pegawai yang bekerja hams mernaruhi aturan serta melaksanakan tanggung jawab untuk mengerjakan semua pekerjaan dengan baik agar mendapat hasil yang maksimal.

Faktor eksternal biasanya timbul dari luar manusia, seperti

a. Kondisi Sepatu

Salah satu faktor eksternal yang menyebabkan kerusakan pada sepatu adalah kondisi sepatu tersebut yang dimana biasanya konsumen yang merniliki sepatu tersebut belum tentu mengetahui kondisi terakhir sepatunya. Maka dari itu perlu adanya ketelitian dari kedua belah pihak untuk memeriksa kembali kondisi sepatu. 
b. Bahan

Bahan yang digunakan untuk mencuci sepatu sangatlah krusial, apabila bahan tidak cocok dengan sepatu maka secara tidak langsung dapat merusak sepatu konsumen. Maka dari itu hendaknya pelaku usaha lebih teliti dan lebih cerdas untuk memilih bahan terbaik.

c. Lingkungan

Faktor lingkungan menjadi salah satu faktor dapat menimbulkan kerusakan pada sepatu konsumen, yang dimana faktor lingkungan (force majeure) tentunya tidak dapat diketahui ataupun diprediksi oleh pihak pelaku usaha maupun konswnen.

\section{Upaya Penyelesaian yang dapat Dilakukan Konsumen Apabila Pelaku Usaha Tidak Bertanggungjawab atas Kerugian yang Diterima Konsumen}

Perlindungan hukum adalah segala upaya pemenuhan hak dan pemberian bantuan untuk memenuhi rasa aman kepada saksi dan/atau korban, perlindungan hukum korban kejahatan berbagai benruk, seperti melalui pemberian restirusi, kompensasi, pelayanan medis, dan bantuan hukum (Soerjono Soekanto, $20142)$.

Mahaputra pada tanggal 19 Januari 2021, yang dirnana saudara Mahaputra sebagai salah satu pengguna jasa cuci sepatu yang menerima kerugian oleh salah satu penyedia jasa cuci sepatu yang tidak disebutkan namanya agar tidak rnencemarkan nama baik dari penyedia usaha tersebut. Awalnya saudara Mahaputra mencuci sepatu yang ia miliki di salah satu penyedia jasa cuci sepatu, satu minggu kemudian setelah sepatunya selesai ia mengambil sepatunya, setelah diperiksa kembali di rurnah dan hendak digunakan, ada kerusakan pada sepatu setelah dicuci, terlihat bagian bawah sepatu robek yang apabila digunakan tidak nyaman seperti biasanya. Atas kerusakan yang diterima, saudara Mahaputra meminta pertanggungjawaban dari pelaku usaha atas kerugian yang diterima karena konsurnen diberikan kesempatan untuk mengajukan keberatan (inspraak) dan yang kedua untuk menyelesaikan permasalahan yang ada (wawancara).

Perlindungan hukum adalah perlindungan akan harkat dan martabat, serta pengakuan terhadap hak-hak asasi manusia yang dimiliki oleh subyek hukum berdasarkan ketentuan hukum dari kewenangan (Hadjon, 1993). Bentuk perlindungan hukum dibagi menjadi dua bentuk, yaitu bentuk perlindungan hukum preventif dan represif. Perlindungan hukum preventif adalah perlindungan yang diberikan oleh pemerintah yang bertujuan untuk mencegah sebelum terjadinya pelanggaran. Perlindungan hukum preventif dapat dilakukan dengan pembinaan terhadap konsumen, agar konsumen tidak terjebak dalam kerugian yang diterima akibat posisi tawar menawar yang tidak seimbang. Di Indonesia belum ada pengaturan khusus mengenai perlindungan hukum preventif ini. Dari wawancara yang penulis Iakukan terhadap tiga pelaku usaha jasa cuci sepatu yang berbeda, ketiga penyedia jasa cuci sepatu tersebut rnelindungi dan bekerja secara profesional dalam memberikan perlindungan terhadap konsumennya, agar konsumen mereka tidak menerima kerugian apabila mencuci sepatu di jasa yang pelaku usaha telah sediakan. Pencegahan yang dilakukan oleh pelaku usaha yang telah diwawancarai oleh penulis tenrunya berbeda dan beragam, namun ada kesamaan dari ketiga pelaku usaha yang diwawancarai oleh penulis yaitu agar konsumen yang menggunakanjasanya mendapat hasil yang maksimal dan mendapat kepuasan atas jasa yang digunakan. Sedangkan Perlindungan hukum represif merupakan perlindungan hukum akhir berupa sanksi seperti denda, penjara, dan hukuman tambahan yang diberikan apabila sudah terjadi sengketa atau telah dilakukan suatu pelanggaran. Undang-Undang Nomor 8 Tahun 1999 tentang Perlindungan Konsumen memfasilitasi para konsumen yang merasa dirugikan dengan mengajukan gugatannya ke pelaku usaha diluar pengadilan yaitu Badan Penyelesaian Sengketa Konsumen (BPSK).

Badan Penyelesaian Sengketa. Konsumen (BPSK) adalah pengadilan khusus bagi konsumen yang diharapkan agar kasus konsumen dengan pelaku usaha berjalan dengan cepat, sederhana, dan murah. Apabila kasus yang ingin diselesaikan oleh konsumen dalam bahasan ini yaitu konsumen jasa cuci sepatu yang dirugikan oleh pelaku usaha, perlu adanya perjanjian tertulis yang ditandatangani oleh kedua belah pihak, hal tersebut guna menjadi bukti fisik bahwa ada perjanjian yang tidak terselesaikan oleh salah satu pihak yang dalam hal ini adalah pelaku usahajasa cuci sepatu.

Pesatnya perkembangan perekonomian di Indonesia menghasilkan variasi produk barang dan/atau jasa yang dapat dikonsumsi. Bahkan dengan adanya kemajuan ilmu pengetahuan dan teknologi terbukti rurut mendukung perluasan ruang gerak transaksi perdagangan barang dan/atau jasa hingga 
melintasi batas-batas wilayah suaru negara (Nugroho, 2008). Dengan adanya hal tersebut, harus disediakan mekanisme penyelesaian sengketa konsumen yang mampu menampung dan menyelesaikan seluruh permasalahan konsurnen tersebut, sebagai realisasi dari salah satu hak konsumen yang diberikan jaminan dalam Undang- Undang Perlindungan Konsumen (Emerson, 2021). Upaya penyelesaian yang dapat ditempuh konsumen apabila pelaku usaha jasa cuci sepatu tidak bertanggung jawab atas kerugian yang diterirna oleh konsumen dibagi menjadi dua yaitu Penyelesaian Sengketa Non Litigasi dan Penyelesaian Sengketa Litigasi.

Penyelesaian sengketa secara non litigasi dapat ditempuh konsumen jasa cuci sepatu untuk mendapatkan haknya kembali. Penyelesaian secara litigasi adalah cara penyelesaian sengketa melalui peradilan. Pihak yang bersengketa saling berhadapan satu sama lain untuk mempertahankan hakhaknya, dan hasil akhir dari suatu penyelesaian secara litigasi menyatakan satu pihak yang menang dan satu pihak Iain kalah. Proses penyelesaian secara litigasi ini tentu jarang sekali dipilih oleh konsumen karena memiliki banyak kekurangan karena litigasi memaksa para pihak pada posisi yang ekstrim dan memerlukan pembelaan atau setiap maksud yang dapat mempengaruhi keputusan.

\section{SIMPULAN DAN SARAN}

\section{Simpulan}

Berdasarkan hasil analisis data, dapat disimpulkan diketahui bahwa ada dua faktor yang menimbulkan kerusakan sepatu konsumen, yaitu faktor internal dan faktor eksternal. Dimana faktor internal berasal dari manusia seperti faktor kelalaian manusia, pengalaman, dan kedisiplinan. Sedangkan faktor eksternal berasal dari luar rnanusia, yang dimana disebabkan dari kondisi sepatu, bahan, serta faktor lingkungan. Upaya hukum yang dapat ditempuh konsumen apabila pelaku usaha tidak bertanggung jawab melalui penyelesaian non litigasi dan litigasi. Dimana konsurnen yang dirugikan oleh pelaku usaha jasa cuci sepatu lebih sering menempuh jalur non litigasi agar lebih efisien serta penyelesaian bisa dilakukan dengan cepat tanpa menindak lanjuti ke jalur pengadilan (litigasi).

\section{Saran}

Dari simpulan penelitian di atas, adapun saran yaitu hendaknya pelaku usaha jasa cuci sepatu khususnya di Denpasar Timur menjaga kompetensi di bidangnya agar tidak terjadi sengketa antara pelaku usaha dan konsumen, serta menjaga kualitas pelayanan agar tidak merugikan konsumen yang menggunakan jasanya. Hendaknya konsumen agar lebih memperhatikan serta mengetahui tentang keberadaan Undang-undang Nomor 8 Tahun 1999 tentang Perlindungan Konsumen.

\section{DAFTAR PUSTAKA}

Atmadja, I. D. G., \& Budiartha, I. N. P. (2018). Teori-teori Hukum. Malang. Setara Press.

Emerson, J. (2021). Alternatif Penyelesaian Sengketa diluar Pengadilan (negosiasi, mediasi, konsiliasi, dan arbitrase). Jakarta. Gramedia Pustaka.

Hadjon, P. M. (1993). Penghantar Hukum Administrasi. University Press.

Handayani, T. (2008). Eksistensi Perusahaan Sebagai Organ Masyarakat. Jurnal Ekonomi Dan Bisnis, 3(6), 173-183.

Lukitaningsih, A. (2013). Iklan yang Efektif sebagai Strategi Komunikasi Pemasaran. Jurnal Ekonomi Dan Kewirausahaan, 13(2), 116-129.

Nugroho, S. A. (2008). Proses Penyelesaian Sengketa Konsumen. Kencana Medua Group.

Subekti. (2002). Hukum Perjanjian. Intermasa.

Susanto, H. (2008). Hak-Hak Konsumen Jika Dirugikan. Jakarta. Visi Media.

Trisno, E. (2017). Perlindungan Hukum Terhadap Pelaku Usaha yang Dirugikan Oleh Konsumen (Studi Kasus Pada Win One Karaoke). 5(3).

Widyani, A. A. D. (2020). Etika Bisnis Perspektif Teori dan praktis. Denpasar. Cv Noah Aletheia. 